\title{
LEVEL OF ENCROACHMENT EFFECT TO EXCELLENT PUBLIC RELATIONS: A STUDY ON COMMUNICATION LEADERS ACTIVITY AT PT. TELKOM INDONESIA
}

\author{
Papilaya Dita*, Kriyantono Rachmat, Wulandari Maulina Pia \\ University of Brawijaya, Malang, Indonesia \\ *E-mail: dita.papilaya@gmail.com
}

\begin{abstract}
This research aims to reveal how far the three kinds of encroachment effect to excellent public relations practice. The phenomenon of public relations encroachment and application of excellence theory has been widely studied. Encroachment is a barrier to 10 factors of excellence to be applied properly. However, no research has been done on the extent of counting the correlation and the influence of encroachment (either authority encroachment, functional encroachment, or structural encroachment) on the application of excellence factors. Research conducted by sending an online questionnaire link to 55 communications leader at PT. Telkom Indonesia whose work location spread throughout the country of Indonesia. The dispersed questionnaire includes statements about authority encroachment, functional encroachment, structural encroachment, and 10 principles of excellence indicators. The results of research state that the level of excellent public relations at PT. Telkom Indonesia can't be categorized as excellent. One of the factors that influence the application of the principle of excellence has not been maximized is because the practice of encroachment is still found. The authority encroachment, functional encroachment and structural encroachment that occurred have a correlation and influence on the successful application of the principle of excellence with different levels. The authority encroachment ranks at the top in terms of correlation and its effect on the application of the principle of excellence, followed by functional encroachment, and then structural encroachment.
\end{abstract}

\section{KEY WORDS}

Communication, communication leader, public relations, authority encroachment, functional encroachment, structural encroachment, excellence theory.

Encroachment occurs when there is a non-public relations professional assignment to manage the public relations function (Dozier, 1988; Lauzen 1991, 1992; Laborde, 2005). Lauzen (1991) found two terms in her research findings, encroachment, and imperialism. As time flies, Lee (2005) divides the encroachment into three, namely: authority encroachment, structural encroachment, and functional encroachment. Encroachment authority involves assigning the wrong personnel to manage the public relations department, structural encroachment occurs when the public relations department is under the control of other departments within an organizational structure, whereas functional encroachment occurs when personnel or non-public relations units do the work that public relations functions. Laborde (2005) found that respondents in his study provided some specific examples of encroachment that they witnessed or experienced. The encroachment form invented by Laborde (2005) corresponds to three forms of encroachment that have been identified by previous studies conducted by Lee (2005). Basically, Lauzen's (1991) study that mentions two terms (encroachment and imperialism) is also in accordance with two of the three types of encroachment proposed by Lee (2005). Imperialism according to Lauzen (1991) is a functional practice performed by non-public relations, this is referred to as functional encroachment by Lee (2005). While the encroachment on Lauzen's journal is a structural position in the public relations department held by personnel with non-public relations education and professional background, in other words, it is called authority encroachment.

Encroachment becomes an obstacle for the public relations department to apply the principle of excellence and reduce the influence of public relations leaders in organizational strategy planning (Laborde, 2005). Other researchers, such as Broom \& Dozier (1983), Kelly 
(1994), dan Lauzen (1991, 1992, 1993, 1995), found that encroachment also limits the effectiveness and quality of public relations functions so that it only acts as a technical. It can ultimately eliminate strategic roles and keep the public relations position away from dominant coalition within an organization. Encroachment becomes a problem especially in the corporate hierarchy by making the role of public relations not as the main function so that distancing public relations from the strategic function so that public relations is not able to run its role excellently. The encroachment situation can be a barrier to the effectiveness of public relations or at least an indicator of the effectiveness of public relations activities based on the excellence theory is difficult to achieve if the encroachment occurs (Kriyantono, 2014). Whereas the theory of excellence describes how the function of public relations is best organized and practiced in an organizational environment, by acting strategically and independently within a company (Grunig, Grunig, \& Dozier, 2002).

\section{LITERATURE REVIEW}

The excellence theory has been proved as a general public relations theory in the United States, Canada, and the United Kingdom (Grunig, 2008). The excellence theory is a normative theory of public relations practice in ideal conditions that put forward the existence of two-way communications. In Indonesia, public relations practices have grown along with the development of democracy (Kriyantono, Amrullah, \& Destrity, 2017). Local wisdom in Indonesia itself has also consistent to apply the two-way symmetrical model (Kriyantono \& Mckenna, 2017). In addition, to the practice of excellent public relations in Indonesia is also related to the term role designation. There are two terms that refer to the similar public relations practitioner in Indonesia, it is Public relations (PR) and Society relations (Humas). People who are referred to as PR turn out to have a better level of public relations better than those called Humas (Kriyantono, 2017). One of the inhibitors of the excellence theory can be applied properly is because of the encroachment phenomenon (Laborde, 2005).

About the encroachment phenomenon, many researchers in Indonesia and western countries have found that there are three kinds of encroachment that prevent public relations become excellent. The three kinds of encroachment that found in the former research are: (1) authority encroachment Lauzen, 1991; 1992; 1993; Kelly, 1994; Ruler dan Lange, 2003; Lee, 2005; Laborde 2005; Laborde \& Pomper, 2006; Bronn, 2014; Silaen, 2017; Astuty, Setyastuti, Maulina, \& Hanief, 2017; Verhoeven, 2014; Falkheimer, et al., 2017), (2) functional encroachment (Lauzen, 1991; Grunig \& Grunig, 1991; Ha \& Ferguson, 2015; Astuty, et al., 2017), and (3) structural encroachment (Putra, 2008; Prasetya, 2016; Kriyatono, 2015; Bronn, 2014; Verhoeven, 2014). Nevertheless, these studies have not discussed how much correlation and strength of influence of authority encroachment, structural encroachment, and functional encroachment to the application of the principle of excellence. In other words, no research has been done whether the three types of encroachment mentioned by Lee (2005) have the same or different strengths in influencing the successful application of the principle of excellence.

Kriyantono (2015) found that the organizational structure at high educational institutions still put the public relations in a variety of positions, but the management of college communications can be said properly enough. Experts and practitioners of public relations in Indonesia (Noeradi, 1993; Dahlan, 1994; Kharsadi, 1994 in Putra, 2008) speaks on the basis of their long experience as a public relations practitioner in an organization, as long as public relations officers have access to top executives, public relations positions in organizational structures are not important. Although according to some experts (Noeradi, 1993; Dahlan, 1994; Kharsadi, 1994 in Putra, 2008) the position of public relations in the organizational structure is less important than having access to top executives, but Putra (2008) adds that in order to gain access to top executives, a public relations officer must be a professional, they must have sufficient qualifications of competencies. This statement from Putra (2008) clearly illustrates that in order to reach top executives, a public relations practitioner must have the skill or competence, which means that it must minimize the authority encroachment. Silaen (2017) found that the authority encroachment causing the 
principle of excellence could not be done properly. Several previous research studies conducted in western countries also mention about encroachment that occurred is influenced by lack of competence (Lauzen, 1992; Kelly, 1994; Bronn, 2014; Verhoeven, 2014; Falkheimer, et al., 2017). The former research findings explain that encroachment is the cause of the principle of excellence can't be applied perfectly, but there are different statement between each kind of encroachment that affects the application of the excellence principles. Based on the description above, the researchers formulate research hypotheses as follows:

H1: Each type of encroachment (authority encroachment, structural encroachment, and encroachment functional) that occur in the organization have different strengths in influencing the application of the principle of excellence.

$\mathrm{H} 2$ : Structural encroachment has less influence in effect the application of the excellence principles than the authority encroachment and functional encroachment.

H3: Authority encroachment have the highest influence in effect the application of the excellence principles than the functional encroachment and structural encroachment.

\section{METHODS OF RESEARCH}

This study was conducted using quantitative methods through questionnaires sent via online media (online survey) to a number of 55 communication leaders PT. Telkom Indonesia whose work location is spread all over Indonesia. The questionnaire consists of 53 statements that accommodate both encroachment and excellence indicators. Answers from the questionnaire were measured using a Likert scale with five categories.

Authority is the amount of power and rights delegated to a position (Allen, 1958). Lee (2005) explains that the competencies of public relations practitioners in managerial capacity influence the authority encroachment. Respondents in this study are the communication leader, where the managerial competencies are absolutely necessary. This is in line with the concept proposed by Lauzen (1992) which conveys that the higher level of implementation of public relations manager role proposed by Broom (1982), manager role aspirations, manager role competencies, and powerful public relations schema, can decrease the possibility of authority encroachment. Therefore, to know the existence of the authority encroachment, researchers use the concept offered by Lauzen (1992) as indicators of the statement in the questionnaire.

Lee (2005) explains that functional encroachment occurs when non-public relations departments perform public relations functions, so it means that functional encroachment does not occur when the public relations department performs its function properly. Therefore, to find out the functional encroachment, six major functions of public relations proposed by Cottone, et al (1985) and the scope of public relations role (Kriyantono, 2012) are used as indicators of functional encroachment levels. Cottone, et al (1985) states that the six major functions of public relations include large-scale events, communication with the public, management, media relations, logistics, and client relations. While Kriyantono (2012) states that the scope of public relations roles includes Publication and Publicity, Event, News, Community Involvement, Identity Media, Lobbying, and Social Investment, which is abbreviated as PENCILS.

To know the existence of structural encroachment, the researcher uses the concept from Lee (2005) which mentions that structural encroachment occurs when the public relations department is under another department in an organizational structure, this is also in accordance with statement from Verhoeven (2014) communication officers in secondary positions (eg under Human Resource and Communication or Marketing and Communications) are not included in the executive level as this usually indicates that communication is seen as a subordinate area. While in determining the indicator of excellence, the researcher uses ten principles of excellence theory proposed by Grunig, et al (1992).

The validity of each item statement is measured using the Pearson Product Moment Correlation formula and the result is valid at the level of significance at the 0.05 level. 
Reliability of the questionnaire is calculated using Cronbach Alpha formula with values above 0.8 . The Cronbach Alpha value above 0.8 indicates that the reliability of the questionnaire is good (George \& Mallery, 2003). The time limit specified for the questionnaire was over three weeks and the questionnaire responded to 46 questionnaires, so the response rate of this study was $84 \%$. The answers of all respondents were analyzed using parametric statistics, with the first classical assumption test and the results were eligible. Especially for structural encroachment, respondents' answers show the same point, so the researcher uses the level of position to measure the correlation and the influence of structural encroachment on applying the principle of excellence. Level of positions owned by each communication leader is an ordinal scale, so the researchers convert the ordinal scale into an interval scale before measuring the level of encroachment and the level of excellence. Researchers divided the level of encroachment into five categories, namely very high category, high, medium, low, and very low, with details of scores as follows:

- Very High, average score between $4.01-5.00$

- High, average score between $3.01-4.00$

- Medium, average score between $2.01-3.00$

- Low, average score between 1.01 - 2.00

- Very Low, average score between $0.01-1.00$

For the level of excellence, researchers divide into five categories, namely the category of excellent, good, medium, less good, and poor, with details of scores as follows:

- Excellent, average score between $4.01-5$

- Good, average score between $3.01-4.00$

- Medium, average score between $2.01-3.00$

- Less Good, average score between $1.01-2.00$

- Poor, average score between 0.01 - 1.00

The correlation between the independent variables (authority encroachment, functional encroachment, and structural encroachment) with the dependent variable (excellence factor) was measured using the Pearson Product Moment Correlation formula. While the influence of the independent variable to the dependent variable is calculated using linear regression formula.

\section{RESULTS AND DISCUSSION}

The results of the calculations indicate that the authority encroachment on communication leader at PT. Telkom Indonesia has an average value of 2.45 , so it is included in the medium category. The functional encroachment has an average value of 1.96 , so it falls into the low category, and the structural encroachment has an average value of 3.39 , so it falls into the high category. In applying the principle of excellence, the calculation results show the value of 3.95 , so it falls into the good category. However, the application of the principle of excellence to PT. Telkom Indonesia can't be categorized as excellent, so the researchers then calculate whether it is correlated and influenced by the encroachment phenomenon that occurs.

The results of correlation calculations between each independent variable (authority encroachment, functional encroachment, and structural encroachment) with the dependent variable (excellence) are as follows:

Pearson Correlation

Authority Encroachment $\quad-, 703$

Functional Encroachment $\quad-, 624$

Structural Encroachment $\quad-, 452$

Each type of encroachment has a negative correlation, which means that the higher the encroachment (authority encroachment, functional encroachment, or structural encroachment) that occurs then correlates with the lower the level of excellent public relations can be achieved. The highest correlation is shown by the authority encroachment 
with a value of 0.703 , the second is indicated by a functional encroachment with a value of 0.624 , and in the third sequence is a structural encroachment with a value of 0.452 .

The results of correlation calculations between all independent variables (authority encroachment, functional encroachment, and structural encroachment) with the dependent variable (excellence) are as follows:

Table 2 - R Value of Model Summary

\begin{tabular}{|c|c|c|c|}
\hline \multicolumn{4}{|c|}{ Model Summary } \\
\hline$R$ & R Square & Adjusted R Square & Std. Error of the Estimate \\
\hline, $769^{\mathrm{a}}$ & 0.591 & 0.562 & 7.216 \\
\hline
\end{tabular}

From Model Summary table, the influence value of all independent variables on dependent variable more specifically can be seen from the value of $R$ multiplied $100 \%$, that is equal to $76,9 \%$, with accuracy level equal to $92,784 \%$ (100\% - Std. Error of the Estimate).

Table 2 - Analysis of Variance Value Significance

\begin{tabular}{|c|c|}
\hline \multicolumn{2}{|c|}{ ANOVA } \\
\hline- & Sig. \\
\hline Regression &, $000^{\mathrm{b}}$ \\
\hline
\end{tabular}

From ANOVA table it appears that the significance value is 0,000 so it can be concluded that all sub-variables (authority encroachment, functional encroachment, and structural encroachment) influence together to the level of excellent public relations.

Table 3 - Coefficient Significance of Three Types of Encroachment

\begin{tabular}{|c|c|c|}
\hline \multicolumn{1}{|c|}{ Coefficients } & Sig. \\
\hline- & $\mathrm{t}$ & 0.000 \\
\hline (Constant) & 25.271 & 0.003 \\
\hline Authority Encroachment & -3.175 & 0.024 \\
\hline Functional Encroachment & -2.340 & 0.037 \\
\hline Structural Encroachment & -2.159 & \\
\hline
\end{tabular}

From the Coefficients table, it can be seen that the least significant value is the encroachment of authority, the second is the functional encroachment and the last is the structural encroachment. Therefore, it can be concluded that the authority encroachment has the highest influence on the success of applying the principle of excellence, then the second is the functional encroachment, and the last structural encroachment which has the lowest level of influence on the application of the principle of excellence than the other two types of encroachment. This explains that $\mathrm{H} 1, \mathrm{H} 2$, and $\mathrm{H} 3$ that have been formulated by the researcher are accepted. The sign in column $t$ in the table shows the negative value, so that the regression model happens is opposite, meaning that the lower level of authority encroachment, the functional encroachment, and the structural encroachment that occurs have an effect on the better application of the principle of excellent.

\section{CONCLUSION}

The principle of excellence that applied in PT. Telkom Indonesia has not been in the excellent category due to the influence of the encroachment phenomenon that occurs. In the research results, it was found that:

1. The three types of encroachment presented by Lee (2005) either authority encroachment, functional encroachment, and structural encroachment have correlation and influence the success of applying the principle of excellence

2. Each kind of encroachment has correlation and influence level of application of the principle of excellence with different level.

3. Each type of encroachment has a negative sign of influence, which means: 
- The higher level of authority encroachment that occurs, the lower the level of excellent public relations that can be achieved.

- The higher level of functional encroachment that occurs, the lower the level of excellent public relations that can be achieved.

- The higher level of structural encroachment that occurs, the lower the level of excellent public relations that can be achieved.

4. The authority encroachment has the highest correlation and influence in relation to the application of the excellence principle. Then the functional encroachment ranks second, and the last is the structural encroachment.

Encroachment is an obstacle for the public relations department to apply the principle of excellence (Laborde, 2005; Broom \& Dozier, 1983; Kelly, 1994; Lauzen, 1991, 1992, 1993, 1995). However, encroachment often occurs in the corporate organization because of increased accountability, heightened competition for influence, dependence on shared resources, and the presence of domain similarity in which two departments share the same skills or tasks which is hard to avoid (Lauzen 1991, 1992, 1993). Referring to the results of this study, to improve the level of excellent public relations which is claimed to increase organizational effectiveness, the organization must be concern to minimize the authority encroachment, functional encroachment, and also structural encroachment that occurs in their public relations unit.

This study, of course, has a limitation, that is, although the respondents of this research are the communication leader whose work location spread all over Indonesia area, this research was done at only one company, that is PT. Telkom Indonesia, so it can't be generalized to all public relations activities on different types of organizations or companies in Indonesia or other country will have the same result. Therefore, further research is expected to conduct research on the effect of encroachment on applying the principle of excellence on the varied organization at different locations so that the results of research on the correlations and the influence of encroachment on the application of the principle of excellence can be found to be more generalized.

\section{REFERENCES}

1. Allen, L. (1958). A management and organization. New York: McGraw-Hill Book Company.

2. Astuty, S., Setyastuti, Y., Maulina, N., \& Hanief, L. (2017). Analisis fungsi dan peran humas dalam upaya implementasi good governance: Studi pada bagian humas sekretariat daerah kota Banjarmasin [Function analysis and role of public relations in the implementation of good governance: study on the public relations department of Banjarmasin city secretariat]. Journal of Communication Studies, 2(1), 100-118.

3. Bronn, P. S. (2014). How others see us: Leader's perceptions of communication and communication managers. Journal of Communications Management, 18 (1), 58-79.

4. Broom, G. M. (1982). A comparison of sex roles in public relations. Public Relations Review, 8 17-22.

5. Broom, G. M. \& Dozier, D. M. (1983). An overview: Evaluation research in public relations. PublicRelations Quarterly, 28(3), 5-8

6. Cottone, L., Wakefield, D. G., Cottone, R. R., North, W. (1985). Public relations roles and functions by organization. Public Relations Review, 11 (4), 29-37.

7. Dozier, D. M. (1988). Breaking public relations' glass ceiling. Public Relations Review, 14, 6-13.

8. Falkheimer, J., Heide, M., Nothhaft, H., Platen, S., Simonsson, C., \& Andersson, R. (2017). Is strategic communication too important to be left to communication professionals?: Managers' and coworkers' attitudes towards strategic communication and communication professionals. Public Relations Review, 43, 91-101.

9. George, D., \& Mallery, P. (2003). SPSS for Windows step by step: A simple guide and reference 11.0 update (4th ed.). Boston: Allyn \& Bacon. 
10. Grunig, J.E. (1991). Conceptual differences in public relations and marketing: The case of health-care organizations. Public Relations Review, 17(3), 257-278.

11. Grunig, J. E. (1992). Excellence in public relations and communication management. NJ: Lawrence Erlbaum Associates.

12. Grunig, L. A., Grunig, J. E., Dozier, D. M. (2002). Excellent public relations and effective organizations: A study of communication management in three countries. London: Laurence Erlbaum Associates.

13. Grunig, J. E. (2008). Excellence theory of public relations. In Donsbach, W. (Ed.). The international Encyclopedia of Communication (pp. 1-3). Blackwell Publishing, Ltd.

14. Ha, J. H., \& Ferguson, M. A. (2015). Perception discrepancy of public relations functions and conflict among disciplines: South Korean public relations versus marketing professionals. Journal of Public Relations Research, 27 (1), 1-21.

15. Horowitz, N.C.H. (2012). Conceptualizing a theoretical model for the practice of public relations in the small business environment. Public Relations Journal of Public Relations Society of America, 6, 1-35.

16. Kelly, K.S. (1994). Fund-raising encroachment and the potential of public relations departments in the nonprofit sector. Journal of Public Relations Research, 6(1), 1-22.

17. Kriyantono, R. (2012). Public relations writing. Jakarta: Kencana.

18. Kriyantono, R. (2014). Teori public relations, perspektif barat \& lokal: Aplikasi penelitian dan praktik [Public relations theory, western and local perspective: research and practical application]. Jakarta: Prenadamedia Group.

19. Kriyantono, R. (2015). The constructions of public relations in communication management of high educational institution in the openness of public information era. Jurnal Pekommas, 18 (2), 117 - 126.

20. Kriyantono, R. (2017). Do the different terms affect the roles? A measurement of excellent and managerial role of business and government public relations practices in Indonesia. Int. Journal of Applied Business and Economic Research, 15(6), 193-209.

21. Kriyantono, R. (2017). The model of public relations practices in Indonesia. Global Journal of Business and Social Science Review, 5(3), 194-197.

22. Kriyantono, R., \& Mckenna, B. (2017). Developing a culturally-relevant public relations theory for Indonesia. Malaysian Journal of Communication, 33(1), 1-16.

23. Laborde, E. J. (2005). Corporate public relations practitioners' perceptions of program evaluation and encroachemnt effect. Florida State University.

24. Laborde E.J., \& Pompper, D. (2006). Public relations program evaluation and encroachment effect in the for-profit sector. Public Relations Review, 32, 77-79.

25. Lauzen, M. M. (1991). Imperialism and encroachment in public relations. Public Relations Review, 17(3), 245-255.

26. Lauzen, M. M. (1992). Public relations roles, intraorganizational power, and encroachment. Journal of Public Relations Research, 4(2), 61-80.

27. Lauzen, M. M. (1993). When marketing involvement matters at the manager level. Public Relations Review, 19 (3), 247-259.

28. Lauzen, M. M. (1995). Public relations manager involvement strategic issue diagnosis. Public Relations Review, 21(4), 287-304.

29. Lee, J. (2005). Encroachment theory. In R.L. Heath. (Ed.). Encyclopedia of public relations (pp. 279-281). California: Sage Publications.

30. Putra, I. G. N. (2008). Konteks historis praktek humas di Indonesia [Historical context of public relations practice in Indonesia]. Jurnal IImu Komunikasi, 6(3), 178-190.

31. Ruler, B.V., \& Lange, R.L. (2003). Barriers to communication management in the executive suit. Public Relations Review, 29, 145-158.

32. Silaen, R. (2017). Kompetensi humas pada kepolisian daerah Sumatera Utara [Public relations competencies in North Sumatera regional police]. Jurnal Interaksi, 1(1), 93-104.

33. Vercic, D. (1997). Are the IABC's excellence principles generic? comparing Slovenia and the United States, the United Kingdom and Canada. J. of Com. Man., 2 (4). 335-356.

34. Verhoeven, P. (2014). Communications officers and the c-suite: a study of financial times global 500 companies. Public Relations Review, 40(3), 606-608. 